\title{
Description of Scientific Normality, Attitudes of Investigation and Interested Career On Physics in Senior High School
}

\author{
Astalini ${ }^{1}$, Dwi Agus Kurniawan ${ }^{2}$, Deti Kurnia Sari ${ }^{3}$, Wawan Kurniawan ${ }^{4}$ \\ Jurusan PMIPA, FKIP Univeritas Jambi, Jambi \\ astalinizakir@unja.ac.id', dwiagus.k@unja.ac.id ${ }^{2}$, detiksari097@gmail.com³, \\ wwnkurnia79@gmail.com ${ }^{4}$
}

Received: January $26^{\text {th }}, 2019$. Revised: March $19^{\text {th }}, 2019$. Accepted: March $21^{\text {st }} 2019$

\section{Keywords :}

Attitude; Scientific Normality;

Investigation; Career in

Physics

\begin{abstract}
The purpose of this study was to determine the description of students' attitudes towards physics in Senior High School 8 Jambi City of Indonesia. This research is quantitative-qualitative research with survey research procedures. The subjects of this study were 170 students. The instruments used were questionnaires and interview sheets. Quantitative data analysis using descriptive statistics while qualitative data analysis using data analysis techniques model Miles and Huberman. The results of the 3 aspects of attitude indicators discussed in this study are on the indicator of normality of scientists as much as $60 \%$ are categorized quite good. While the attitude towards investigation in physics is $51 \%$ in the good category. Then in the indicator of interest in a career in the field of physics as much as 58\% of students are categorized well.
\end{abstract}

\section{INTRODUCTION}

Physics is an abstract subject that requires high-level thinking that makes it difficult for students to understand lessons in physics. The difficulties experienced by students in understanding physics lessons during the school period cause deeper difficulties when they are in college [1]. In addition to subjects that are abstract, students' internal factors such as attitudes toward physics are also one of the difficulties that occur in learning physics. As is known that this attitude is very referring to the behavior and emotional person [2]. Attitudes will be seen when the learning process takes place. The attitude of students in learning can be described by feeling like or disliking a subject. The importance of knowing student attitudes in learning has a positive effect in improving learning achievement.

Student attitudes are the keys to achieving success in mastery and student academic achievement [3]. As is known if students have a positive attitude towards learning will have a major influence on learning. If students have a positive attitude towards learning can improve learning achievement [4]. Likewise, students' attitudes towards physics learning, if students behave positively towards physics learning the results of learning physics and science will increase. Student's positive attitude towards physics occurs when students are able to understand more deeply about the concepts of physics and make learning more effective in their environment. The negative attitude of students in learning 
physics causes students' learning achievement to be bad. Good or bad physics learning outcomes are influenced by student attitudes during the learning process, which is known that if students behave negatively towards learning physics will make learning now or in the future more difficult [5]. Students' attitudes toward physics can be identified by identifying indicators of scientific normality, attitudes toward inquiry in physics, adoption of scientific attitudes, and interest in a career in physics.

The normality aspect of the scientist describes how students see scientists and place themselves as science learners. Normality scientists can be said to be an illustration of a scientist also called the perception of scientists. Normality of scientists is someone who looks ordinary and the same as ordinary people. A scientist is often portrayed in the mass media. According to students describing scientists as bearded/bespectacled parents who always work in the laboratory, record new findings and read books [6]. A scientist can solve a problem and find something new. Attitudes drew from scientists in solving problems and finding new discoveries that can be used as role models for students. In physics learning, for example, students in the class are diligent in writing and diligent in learning. In addition, during the practicum of physics students can assemble the equipment properly in accordance with the procedure and diligently conduct experiments. Besides the normality of scientists, attitudes toward inquiry in physics also influence physics learning.

Attitudes toward inquiry in physics are students' views or actions in solving problems that occur in physics. Inquiry refers to combining scientific processes with scientific knowledge and reasoning and critical thinking [7]. Investigations in physics can be seen how students solve problems that occur in the classroom. So many ways to solve problems scientifically, namely measuring, identifying and experimenting on a scientific scale to find strong information [8]. One of the investigative activities in physics conducted by students is conducting experiments. Experiments conducted by students can develop students' beliefs during school that in order to obtain conclusions it is necessary to have steps that must be followed in a scientific method to find out to produce new knowledge [9]. The attitude of students in physics inquiry can form to increase the activity of students in learning. The students' creativity in learning relates to the scientific attitude that the student has.

Scientific attitude is one of the important aspects of science [10]. Scientific attitudes can form student mindsets critically. The importance of a scientific attitude that must be possessed by a student is to gain knowledge in various fields. Complex and abstract learning of physics requires students to behave scientifically. Scientific attitudes can be described by expressions or reactions that show in accordance with scientific ethics [11]. With students being able to behave scientifically will help obtain good learning outcomes [12]. Students with a high scientific attitude will have a positive attitude towards physics so that they can provide good learning outcomes.

Physics learning outcomes and student attitudes will influence students in their interest in a career in physics. If students are negative towards physics, the student does not have an interest in a career in physics. A positive attitude and interest in physics will cause future careers in the field of physics to increase. Difficulties in physics cause students not to be interested in a career in physics Many students who hold physics are boring and for a career in physics is a hard job. One that influences students to have a career in physics is interest or interest. Therefore, to be able to improve students in a career in the field of physics, it is important to pay attention to their interests, which interest greatly affects their career and personal life [13].

The purpose of this study was to find out the attitudes of students towards physics subjects in high school precisely in Senior High School 8 Jambi City of Indonesia. Indicators used in identifying students' attitudes towards physics subjects include normality of scientists, attitudes toward inquiry in physics, adoption of scientific attitudes, and interest in a career in physics. In this study the research questions are as follows:

1. How to describe indicators of student attitudes in physics?

2. What problems are faced in improving student attitudes?

3. How to improve student attitudes on physics subjects 
The findings of this study can contribute to improving students' attitudes towards physics learning. This research is very important, especially at the high school level because attitudes can affect learning outcomes.

\section{METHOD}

\section{Research Design}

The design used by researchers is quantitative research using the survey research design. Survey research is a procedure that administers a sample or to an entire population that is used to describe attitudes, opinions, behavior, or special characteristics of the population [14]. The design of this study was applied because it was in accordance with the objectives of the study, where the aim was to know the Attitudes of High School Students towards Physics subjects.

\section{Subjects}

Subjects in this study were students at Senior High School 8 City Jambi of Indonesia. As a whole totaling 170 students. The sample was taken based on the total sampling technique. Subjects were students of class X, XI, and XII from the MIPA department with a composition of 92 female students and 78 male students.

\section{Research Instruments}

This study used 2 instruments, namely questionnaires and interview sheets. The questionnaire used was an adoption from the [15]. There were 54 valid statements with a measuring scale, namely the Likert scale. The scale consists of 5 points of value, namely strongly agree is 5 , agree that is 4 , neutral is 3 , disagree that is 2 , and strongly disagree is 1 . Each item statement is representative of 7 attitude indicators. In this study focused on 4 indicators of attitudes, namely normality of scientists, attitudes toward inquiry in physics, the adoption of scientific attitudes, and interest in a career in physics. The following is a table that shows the classification of statements based on focused indicators.

Table 1. Indicator of Attitudes

\begin{tabular}{clc}
\hline No & \multicolumn{1}{c}{ Indicator } & Statement Number \\
\hline 1 & Scientific Norm & $2,9,16,23,30$ \\
2. & Attitudes towards Investigation in Physics & $3,10,17,24,31,36,41,46,50$ \\
3 & Career Interest in Physics & $7,14,21,28,35,40,45,49,52,54$ \\
\hline
\end{tabular}

In addition to questionnaires, data is also taken through interviews with students in each class of research subjects. The goal is to be able to obtain a subjective view of students towards physics learning. The interview guide was created and developed based on the attitude indicators used in the questionnaire.

\section{Research Procedure}

The study was conducted in several stages. In the first stage, the proposal is made and formulates the problem and its variables. After that the literature review is carried out, namely looking for theories that support and deepen the discussion of the problem under study in order to obtain an overview of the research design and the instruments needed. Then, at the stage of data retrieval, the questionnaire was given to students in Senior High School 8 City Jambi of Indonesia. Interviews were also conducted for students in each class with 3 people representing. From the acquisition of the data then it is analyzed, namely data coding, proper data filtering and analysis from the results of sorting the data.

\section{Data Analysis}

The results of the data obtained are described using descriptive statistics. Descriptive statistics present large amounts of data that include mode, mean, median, maximum, minimum, and standard deviation 
[16]. The analysis was carried out using the SPSS 24 program to obtain the percentage, frequency, average and standard deviation of the data. The qualitative data from the interviews were analyzed content using the Miles and Huberman models.

\section{RESULTS AND DISCUSSIONS}

\section{Scientific Normality}

The results of processing descriptive statistical data on indicators of student scientist normality towards physics subjects can be seen from the following table:

Table 2. Scientific Normality in Senior High School 8 Jambi City of Indonesia

\begin{tabular}{|c|c|c|c|c|c|c|c|c|c|c|}
\hline \multicolumn{3}{|c|}{ Classification } & \multirow{2}{*}{ Mean } & \multirow{2}{*}{ Median } & \multirow{2}{*}{ Mode } & \multirow{2}{*}{ Range } & \multirow{2}{*}{$\begin{array}{c}\text { Std. } \\
\text { Deviation }\end{array}$} & \multirow{2}{*}{ Min } & \multirow{2}{*}{$\operatorname{Max}$} & \multirow{2}{*}{$\%$} \\
\hline Interval & Category & Total & & & & & & & & \\
\hline $5.0-9.0$ & Very not good & 0 & & & & & & & & $0 \%$ \\
\hline $9.1-13.0$ & Not good & 8 & & & & & & & & $5 \%$ \\
\hline $13.1-17.0$ & Enough & 102 & 16.9595 & 17 & 17 & 12 & 1.98939 & 10 & 22 & $60 \%$ \\
\hline $17.1-21.0$ & Good & 57 & & & & & & & & $33 \%$ \\
\hline $21.1-25.0$ & Very good & 3 & & & & & & & & $2 \%$ \\
\hline & otal & 170 & & & & & & & & $100 \%$ \\
\hline
\end{tabular}

In table 2, there were $60 \%$ of students having quite good categorical attitudes with maximum scores of the overall statement on the indicator is 22 . Then the good attitude category for students is $33 \%$. And for categorical very good attitude $2 \%$. In this case, the students seem to have understood how scientists work. The attitude score is not good $5 \%$ and the attitude is very bad at $0 \%$. This shows that only a few students still cannot see themselves as scientists.

The results of the analysis of table 2 with indicators of scientist normality in students in SMA 8 Jambi City showed that the majority of students were in a fairly good category. The results of this questionnaire describe that students are able to position themselves as scientists and imitate scientist thinking while studying. While the results of the interview are presented as follows.

Question : Do you know physics scientists? If yes, what do you think about the lives of these scientists in their daily lives?

Answer : Yes. I only know their names and services. For example, like Newton. their lives, maybe just like humans in general. Eat, sleep, work, and have a family.

Question : Do you think scientists can have a happy marriage or family? Explain the reason!

Answer : Yes you can. Maybe, I am not sure. Don't think about that yet. What is clear is that scientists are just like everyone else.

From the interview, students imagined that scientists also had a normal side of life. It shows students do not explore scientists as a closed person who is quiet, unable to socialize and be alienated from people's lives. Students regard scientists as realistic people, inventors and problem solvers, do many things, unique, and thinkers [17]. Scientific normality assesses how students see scientists and place themselves as learners of science. However, in reality, students are still often confused with professions related to science [18].

Attitudes Toward Investigations in Physics

The results of the processing of descriptive statistical data on indicators of student attitudes toward physics research can be seen from the following table: 
Description of Scientific Normality, Attitudes of Investigation and Interested Career On Physics... Astalini, Dwi Agus Kurniawan, Deti Kurnia Sari, Wawan Kurniawan

Table 3. Attitudes Toward Investigations of Physics in Senior High School 8 Jambi City of Indonesia

\begin{tabular}{|c|c|c|c|c|c|c|c|c|c|c|}
\hline \multicolumn{3}{|c|}{ Classification } & \multirow{2}{*}{ Mean } & \multirow{2}{*}{ Median } & \multirow{2}{*}{ Mode } & \multirow{2}{*}{ Range } & \multirow{2}{*}{$\begin{array}{c}\text { Std. } \\
\text { Deviation }\end{array}$} & \multirow{2}{*}{ Min } & \multirow{2}{*}{ Max } & \multirow{2}{*}{$\%$} \\
\hline Interval & Category & Total & & & & & & & & \\
\hline $9.0-16.2$ & Very not good & 0 & & & & & & & & $0 \%$ \\
\hline $16.3-23.4$ & Not good & 5 & & & & & & & & $3 \%$ \\
\hline $23.5-30.6$ & Enough & 66 & 31.4971 & 31 & 32 & 24 & 4.18139 & 19 & 43 & $39 \%$ \\
\hline $30.7-37.8$ & Good & 86 & & & & & & & & $51 \%$ \\
\hline $37.9-45.0$ & Very good & 12 & & & & & & & & $7 \%$ \\
\hline & tal & 170 & & & & & & & & $100 \%$ \\
\hline
\end{tabular}

In table 3, there is $39 \%$ of students have attitudes categorized quite well with the maximum score of the overall statement on the indicator is 43 . Then the category of good attitude on students is $51 \%$ and the attitude is very good 7\%. This shows that the majority of students have a good attitude on attitude indicators towards investigations in physics. Not good attitude score 3\% and very bad attitude at $0 \%$.

In table 3, there is $39 \%$ of students have attitudes categorized quite well with the maximum score of the overall statement on the indicator is 43 . Then the category of good attitude on students is $51 \%$ and the attitude is very good $7 \%$. This shows that the majority of students have a good attitude on attitude indicators towards investigations in physics. Not good attitude score $3 \%$ and very bad attitude at $0 \%$.

The results of data analysis from investigative physics attitude indicators in in Senior High School 8 City Jambi of Indonesia showed that students' dominant attitudes were in a good category. Based on the results of interviews with well-categorized students who have an active attitude in finding things that conflict with the experimental results, students respond critically, have high curiosity and never give up.

Question : How do you feel when doing experiments? Explain the reason.

Answer : I like it. Conduct experiments / experiments. By doing experiments, physics lessons are not boring. I also know the application of the laws of physics.

Question : If you have difficulty finding answers or certain things during an experiment, would you rather look for your own answers or ask friends?

Answer : If I still can, I prefer to find out myself and read in my book. But if you don't know, I just asked the teacher or friend.

The results of interviews conducted showed that the students liked the experimental activities, which indicated that the students like to think critically, find interesting new things from physics through the investigation they did. One of the obstacles to the learning process of physics is the lack of students thinking scientifically about Physics based on concepts so that in learning abstract things. By conducting experiments, abstract physics becomes easier to understand and attract students. With experiments students can develop their ability to think critically and to get conclusions that are needed step by step that must be followed in a scientific method. Experimental activities carried out can increase student activity and self-confidence both in conducting experiments and in learning activities. [19]. The increase in investigation activities is influenced by self-confidence in their ability to study science. The experimental activities can also increase high curiosity, it seems that students like to ask questions and find solutions when conducting investigations. Forms of appreciation and support for a scientific inquiry from students show that they value the scientific way of gathering evidence, thinking creatively, thinking rationally, responding to and communicating, conclusions because they face life situations related to science [20].

\section{Career Interest in Physics}

The results of the processing of descriptive statistical data on indicators of career interest in physics can be seen from the following table: 
Table 4. Interest in a career in physics in Senior High School 8 Jambi City of Indonesia

\begin{tabular}{|c|c|c|c|c|c|c|c|c|c|c|}
\hline \multicolumn{3}{|c|}{ Classification } & \multirow{2}{*}{ Mean } & \multirow{2}{*}{ Median } & \multirow{2}{*}{ Mode } & \multirow{2}{*}{ Range } & \multirow{2}{*}{$\begin{array}{c}\text { Std. } \\
\text { Deviation }\end{array}$} & \multirow{2}{*}{ Min } & \multirow{2}{*}{$\operatorname{Max}$} & \multirow{2}{*}{$\%$} \\
\hline Interval & Category & Total & & & & & & & & \\
\hline $10.0-18.0$ & Very not good & 2 & & & & & & & & $1 \%$ \\
\hline $18.1-26.0$ & Not good & 21 & & & & & & & & $12 \%$ \\
\hline $26.1-34.0$ & Enough & 27 & 32.18 & 32 & 31 & 28 & 5.125 & 18 & 46 & $16 \%$ \\
\hline $34.1-42.0$ & Good & 98 & & & & & & & & $58 \%$ \\
\hline $42.1-45.0$ & Very good & 22 & & & & & & & & $13 \%$ \\
\hline & tal & 170 & & & & & & & & $100 \%$ \\
\hline
\end{tabular}

In table 4 , there were $16 \%$ of students having a fairly good category with a maximum score of all statements on the indicator is 46 . Then the category of a good attitude towards students is $58 \%$ and a very good attitude is $13 \%$. This shows that most students have an interest in a career in physics. The attitude score is not good $12 \%$ and a very bad attitude is $1 \%$.

The results of the analysis on the indicators of interest in a career in the field of physics in Senior High School 8 City Jambi of Indonesia showed students to be in a good category. Students think that being a scientist and working in a laboratory is very interesting. They have an interest in working with physics inventors. But most are not interested in teaching physics. As for the results of interviews, students are presented as follows.

Question : Are you interested in a career in physics?

Answer : Yes, I want to have a career in physics but not to become a teacher because being a teacher is a hard job.

The interview results show that students are interested in a career in physics, but not for teaching. Being a physics teacher or the like is too heavy for them. Interest and interest are the main keys to improving students for a career in physics. To be able to improve students in a career in the field of physics needs to pay attention to their interests which interest greatly influences career achievements and personal life Students who are interested in jobs related to the concept of physics, they will study harder to understand it. The existence of extensive job opportunities and the possibility of great success in the field of physics can also be a driving factor for students' desire to pursue a career in physics.

\section{Problems}

There are several obstacles faced by students in each indicator. In the indicator of normality, there are $5 \%$ or 8 students from 170 students who have an attitude that is in the bad category. The obstacle faced by these students is the lack of knowledge about scientific scientists which causes them to assume that physics can only be understood by people who are geniuses. On attitude indicators towards investigations in physics, there are $3 \%$ or 5 students who have a bad attitude towards investigations in physics. The obstacles faced by these students are that they do not know to do experiments, and are less active when the activities take place. Less active and usable for students to carry out experiments because these students do not like physics because they think physics is difficult. While the indicators of career interest in physics are $13 \%$ or 23 students have an attitude that is not good. The low results of led physics learning to a lack of a career in physics.

\section{CONCLUSION AND SUGGESTION}

Based on the research that has been done, the indicators of scientific normality are quite good because most students know the life processes of scientists before becoming a famous scientist. Students know that physics scientists also go through the process of learning like other normal people, namely to 
learn and understand tenaciously the things that make them curious and not afraid to fail in experimenting. On attitude indicators towards investigations in physics are dominant in the good category because some students like experimental activities indicate that these students like to think critically, find interesting new things from physics through the investigation they do. While the indicators of career interest in physics are dominant in the good category where students who have the dominant attitude are students who like physics and they have a high level of curiosity towards physics materials. Complex and abstract physics subjects cause many students to find it difficult to learn so students have a negative attitude towards physics subjects. This negative attitude will have a negative impact on the achievement of student learning outcomes. Therefore the importance of the teacher knows the student's attitude towards a subject. Choosing cool learning methods and strategies will help students to be positive about a subject.

\section{REFERENCES}

[1] Guido, R. M. (2013). Attitude and Motivation towards Learning Physics. International Journal of Engineering Research \& Technology, 2(11): 2087-2094. https://doi.org/10.1093/nar/gkn1085.

[2] Barbara, L. M. (1986). The Affective And Cognitive Domains: Integration For Intruction And Research. New Jersey: Educational Technology.

[3] Nordin, A., \& Ling, L. H. (2011). Hubungan Sikap Terhadap Mata Pelajaran Sains Dengan Penguasaan Konsep Asas Sains Pelajar Tingkatan Dua, 2(June): 89-101.

[4] Veloo, A., Nor, R., \& Khalid, R. (2015). Attitude towards physics and additional mathematics achievement towards physics achievement. International Education Studies, 8(3): 35-43. https://doi.org/10.5539/ies.v8n3p35

[5] Erdemir, N. (2009). Determining students ' attitude towards physics through problem-solving strategy. Asia-Pacific Forum on Science Learning and Teaching, 10(2): 1-19.

[6] Christidou, V. (2012). Interest, attitudes and images related to science: Combining students' voices with the voices of school Science, teachers, and popular science. International Journal of Environmental \& Science Education, 6(2): 10. https://doi.org/10.2802/35544.

[7] Lederman, N. G., Lederman, J. S., \& Antink, A. (2013). Nature of Science and Scientific Inquiry as Contexts for the Learning of Science and Achievement of Scientific Literacy. International Journal of Education in Mathematics, Science and Technology, 1(3): 138-147. Retrieved from www.ijemst.com

[8] Welch, A. G. (2010). Using the TOSRA to assess high school students' attitudes toward science after competing in the first robotics competition: An exploratory study. Eurasia Journal of Mathematics, Science and Technology Education, 6(3): 187-197. https://doi.org/10.12973/ejmste/75239.

[9] Moeed, A. (2013). Science investigation that best supports student learning: Teachers understanding of science investigation. International Journal of Environmental and Science Education, 8(4): 537-559. https://doi.org/10.12973/ijese.2013.218a

[10] Khan, A., Shah, A., \& Mahmood Zareen, R. (2012). Scientific Attitude Development at Secondary School Level: A comparison between methods of teaching language. Review in India: 439-445.

[11] Pitafi, A. I., \& Farooq, M. (2012). Measurement of Scientific Attitude of Secondary School Students in Pakistan. Academic Rearch International, 2(2): 379-392. https://doi.org/10.1002/mrm.24433

[12] Fakhruddin, Eprina, E., \& Syahril. (2010). Sikap Ilmiah Siswa Dalam Pembelajaran Fisika Dengan Penggunaan Media Komputer Melalui Model Kooperatif Tipe Stad Pada Siswa Kelas X3 SMA Negeri I Bangkinang BaraT. Jurnal Geliga Sains, 4(1): 18-22.

[13] Kurbanoğlu, İ., \& Arslan, S. (2015). High school students' educational and career interest (science-technology-mathematics) and career adaptabilities. Australian Council for Educational Research, 24(3): 166-172. https://doi.org/10.1177/1038416215594633

[14] Creswell, J. W. (2012). Educational Research: Planning, Conducting, And Evaluating 
JIPF, Vol. 4 No. 2, September 2019

Quantitative And Qualitative Research. New Jersey: Pearson Educational Inc.

[15] Darmawangsa, R. (2018). Pengembangan Instrumen Sikap Siswa Sekolah Menengah Atas Mata Pelajaran Fisika. Jurnal Pendidikan Fisika Universitas Muhammadiyah Makassar, 6(1): 107114.

[16] Cohen, L., Manion, L., \& Morrison, K. (2007). Research Methods in Education. New York: Routledge.

[17] Balçın, M. D., \& Ergün, A. (2018). Secondary School Students' Perceptions and Attitudes About Scientists. European Journal of Education Studies, (March). https://doi.org/10.5281/zenodo.1206989

[18] Leblebicioglu, G., Metin, D., Yardimci, E., \& Cetin, S. C. (2011). The effect of informal and formal interaction between scientists and children at a science camp on their images of scientists. Science Education International, 22(3): 158-174.

[19] Stefan, M., \& Ciomos, F. (2010). The 8Th And 9Th Grade Students' Attitude Towards Teaching And Learning Physics. Acta Didactica Napocensia, 3(3): 7-14.

[20] Bybee, R., McCrae, B., \& Laurie, R. (2009). PISA 2006: An assessment of scientific literacy. Journal of Research in Science Teaching, 46(8): 865-883. https://doi.org/10.1002/tea.20333 